\title{
Patojen Gram-Pozitif Anaerop Kokların Antimikrobiyal İlaçlara Duyarlılıkları: Türkiye'den Bir Üniversite Hastanesi Verileri
}

\author{
Antimicrobial Susceptibility of Pathogenic Gram-positive \\ Anaerobic Cocci: Data of a University Hospital in Turkey
}

\author{
Öncü AKGÜL ${ }^{1}(I D)$, Güner SÖYLETiR' (ID), Nurver ÜLGER TOPRAK (ID) \\ ${ }^{1}$ Marmara Üniversitesi Tıp Fakültesi, Tıbbi Mikrobiyoloji Anabilim Dalı, İstanbul. \\ ${ }^{1}$ Marmara University Faculty of Medicine, Department of Medical Microbiology, Istanbul, Turkey.
}

* Bu çalışma, Marmara Üniversitesi Bilimsel Araştırma Projeleri Komisyonu Başkanlığı tarafından SAG-C-DRP-130515-0166 numaralı proje ile desteklenmiştir.

Makale Atıfı: Akgül Ö, Söyletir G, Ülger Toprak N. Patojen gram-pozitif anaerop kokların antimikrobiyal ilaçlara duyarlııkları: Türkiye'den bir üniversite hastanesi verileri. Mikrobiyol Bul 2020;54(3):404-417.

\section{ÖZ}

Büyük bir anaerop bakteri topluluğu olan gram-pozitif anaerop koklar (GPAK), insan deri ve mukoza yüzeylerinin normal mikrobiyota üyeleridir. Herhangi bir yaralanma sonrasında veya bağışık yanıtın baskılandığı durumlarda invaziv, çoğunlukla mikst enfeksiyonlara neden olabilirler. GPAK, en sık izole edilen anaerop enfeksiyon etkenleri arasında ikinci sırada yer alır. Sınırı sayıda çalışma olmakla birlikte, GPAK'ların antimikrobiyal ilaçlara direnç geliştirdikleri bildirilmiş̧ir. Antimikrobiyal ilaçlara dirençli patojenlerin uygun olmayan antimikrobiyal ilaçlarla tedavisi başarısız klinik sonuçların alınmasına neden olmaktadır. Bu yüzden merkezlerin periyodik olarak, klinik öneme sahip anaerop bakterileri direnç eğilimleri açısından izlemeleri önerilmektedir. Çalışmamızda klinik örneklerden izole edilen GPAK'ın antibiyotik duyarlııı durumlarını belirlemek amaçlanmıştır. Çalışmaya 2013-2015 yılları arasında Marmara Üniversite Hastanesinde izole edilen, tekrar etmeyen 100 patojen GPAK alınmıştır. İzolatlar, geleneksel yöntemler, "matrix-assisted laser desorption ionization-time of flight mass spectrometry system (MALDI-TOF MS)" (VITEK MS; v3.0, bioMerieux, Fransa) ve 16S rRNA gen dizi analizi ile tanımlanmışır. Antimikrobiyal duyarlııı testi, "Clinical and Laboratory Standards Institute (CLSI)" önerilerine göre agar dilüsyon yöntemiyle gerçekleştirilmiştir. Antibiyotik duyarlılık testi ile penisilin, amoksisilin/klavulonik asit (AMC), sefoksitin, meropenem, klindamisin, eritromisin, tetrasiklin, tigesiklin, kloramfenikol, moksifloksasin ve metronidazol antibiyotikleri çalışılmıştır. Minimum inhibitör konsantrasyonu (MiK) sonuçları "European Committee on Antimicrobial Susceptibility Testing (EUCAST)" sınır değerlerine göre yorumlanmıştır. EUCAST rehberinde MiK sınır değerleri bulunmayan sefoksitin, tetrasiklin ve moksifloksasin için CLSI, tigesiklin için ise "Food and Drug Administration (FDA)" MiK sınır değerleri ölçü alınmıştır. Yüz izolatın beş farklı GPAK; Parvomonas (\%40), Finegoldia (\%34), Peptoniphilus (\%14), Peptostreptococcus (\%10) ve Anaerococcus (\%1) cinsinden oluştuğu saptanmıştır. Mikroorganizmaların tamamı meropenem, tigesiklin ve metronidazole duyarlı bulunmuştur. İzolatların penisilin, AMC, sefoksitin ve kloramfenikole oldukça duyarlı oldukları saptanmış ve duyarlı olmayan izolat oranı $\% 5$ veya daha az bulunmuştur. Klindamisin, tetrasiklin ve moksifloksasine 
direnç oranları ise sırasıyla; $\% 14, \% 31$ ve $\% 24$ olarak belirlenmiştir. İzolatların $\% 11$ 'i çok ilaca direnç göstermiştir. Metronidazol ve tigesiklin GPAK'a karşı yüksek in vitro aktivite göstermişlerdir, her ikisinin ampirik tedavi için seçilecek uygun antimikrobiyaller olduğunu söyleyebiliriz. Meropenemin etkinliği de yüksek bulunmuş ancak bu antimikrobiyalin direnç potansiyeline sahip diğer mikroorganizmaların eşlik ettiği ağır mikst enfeksiyonların tedavisinde kullanılmasının daha doğru olacağı izlenmiştir. GPAK enfeksiyonunun tedavisinde sıklıkla kullanılan penisilin ve AMC'ye dirençli izolatların saptanması, GPAK'ın antimikrobiyal duyarlıık paternlerinin periyodik olarak izlenmesini gerekli kılmaktadır. Klindamisin, tetrasiklin ve moksifloksasine karşı yüksek direnç oranları, bu antimikrobiyal ilaçların, etkenin antimikrobiyal duyarlılık sonucu belirlenmeden enfeksiyon tedavisi için kullanılmaması gerektiğini göstermektedir. Bu çalışma, Türkiye'de bugüne kadar yapılmış en fazla GPAK izolatının ele alındığı duyarlıık çalışmasıdır. Sonuçlarımızın gerek hastanemiz gerekse ülkemiz için iyi bir sürveyans verisi olacağını düşünmekteyiz.

Anahtar kelimeler: GPAK; antimikrobiyal duyarlıı; agar dilüsyon; MALDI-TOF MS; 165 rRNA geni.

\section{ABSTRACT}

Gram-positive anaerobic cocci (GPAC), a large group of anaerobic bacteria, are the members of the normal microbiota that colonizes the skin and mucosal surfaces of the human body. However, in case of a wound or when the host becomes immunocompromised, GPAC can cause invasive and most frequently mixed infections. GPAC are the second most frequently isolated bacteria in anaerobic infections. Although the studies are limited, GPAC have been reported to develop resistance to antimicrobial drugs. The resistance of the pathogens to the antimicrobials and improper therapy can cause poor clinical outcomes. Therefore, monitoring of the resistance trends of regional clinically important anaerobic bacteria periodically is recommended. In our study, we aimed to determine the antimicrobial susceptibility profiles of clinically important GPAC. A total of 100 non-duplicated pathogenic GPAC isolates were collected from Marmara University Hospital between 2013 and 2015. The isolates were identified by using conventional methods, "matrix-assisted laser desorption ionization-time of flight mass spectrometry system (MALDI-TOF MS)" (VITEK MS; v3.0, bioMerieux, France) and 16S rRNA gene sequencing. Antimicrobial susceptibility test was carried out by the agar dilution method according to the Clinical and Laboratory Standards Institute (CLSI) guidelines. The following antimicrobials were tested: penicillin, amoxicillin/ clavulanic acid (AMC), cefoxitin, meropenem, clindamycin, erythromycin, tetracycline, tigecycline, chloramphenicol, moxifloxacin and metronidazole. The minimum inhibitory concentration (MIC) results were interpreted according to the breakpoints described by the European Committee on Antimicrobial Susceptibility Testing (EUCAST). Breakpoints recommended by CLSI for cefoxitin, tetracycline and moxifloxacin, and breakpoint recommended by Food and Drug Administration (FDA) for tigecycline were used since there were no EUCAST breakpoints for these antimicrobials. $\mathrm{MIC}_{50}$ and $\mathrm{MIC}_{90}$ values were determined for erythromycin since the breakpoint was not described by EUCAST, CLSI or FDA guidelines. The identification results showed that the strains $(n=100)$ consisted of five different GPAC genus; Parvomonas (40\%), Finegoldia (34\%), Peptoniphilus (14\%), Peptostreptococcus (10\%) and Anaerococcus (1\%). All of the organisms were susceptible to meropenem, tigecycline and metronidazole. The isolates were highly susceptible to penicillin, AMC, cefoxitin, and chloramphenicol, since the resistance rates against these antimicrobials were $5 \%$ or less. The resistance rates against clindamycin, tetracycline and moxifloxacin were $14 \%, 31 \%$ and $24 \%$, respectively. In total, $11 \%$ of the isolates were multidrug resistant. Metronidazole and tigecycline displayed high in vitro activity against GPAC and both are appropriate antimicrobials for the selection of empiric therapy. The effectiveness of meropenem was also found high, but it was observed that this antimicrobial would be more appropriate to use in the treatment of severe mixed infections accompanied by other microorganisms with the resistance potential. Detection of penicillin and AMC resistant isolates, which are frequently used in the treatment of GPAC infection, requires periodic monitoring of the antimicrobial susceptibility patterns of GPAC. The high rates of resistance against clindamycin, tetracycline and moksifloxacin indicated that these antimicrobials should not be used for empirical treatment of infections without prior antimicrobial susceptibility testing. This study is one of the largest susceptibility studies specifically carried out on GPAC to date in Turkey. We believe that our results will provide good surveillance data both for our hospital and our country.

Keywords: GPAC; antimicrobial susceptibility; agar dilution; MALDI-TOF MS; 16S rRNA gene. 


\section{Giriş̧}

Gram-pozitif anaerop koklar (GPAK), kommensal mikrobiyotanın önemli bir kısmını oluşturur. Günümüzde tanımlanmış GPAK'lara ait 13 cins (Peptococcus, Peptostreptococcus, Finegoldia, Parvimonas, Anaerococcus, Peptoniphilus, Gallicola, Murdochiella, Atopobium, Anaerosphaera, Coprococcus, Sarcina, Blautia) bulunmaktadır. GPAK'lar deri veya mukoza bütünlüğünün bozulduğu durumlarda steril vücut bölgelerine ulaşarak endojen kaynakı ınfeksiyonlara yol açabilir. Klinik örneklerden izole edilen anaerop bakterilerin yaklaşık \%25-30'unu oluştururlar. Sıklıkla enfeksiyona yol açmalarına karşın literatürde GPAK'larla ilgili çalışmalar sınırıdır ${ }^{1}$.

GPAK'lar oksijene son derece duyarlı mikroorganizmalardır. Bu nedenle gerek klinik örneklerin alınması ve taşınmasında, gerekse üretilmelerinde özel anaerop koşulların sağlanması gereklidir. Ancak tanı laboratuvarlarının birçoğunda anaerop taşıma sistemi ve anaerop bakterilerin üretilmesi için anaerop ortam bulunmamaktadır. Ayrıca bu mikroorganizmaların üremelerinin yavaş olması ve tanımlanmalarında kullanılan fenotipik yöntemlerin uzun zaman alması GPAK'larla ilgili çalısmaların kısıtlı olmasında önemli etkendir. Diğer yandan, GPAK'lar genellikle diğer mikroorganizmalarla beraber mikst enfeksiyonlara yol açabilmektedir. Mikst kültür ortamında hızı üreyen ve daha büyük koIoniler oluşturan bakterilerin arasında küçük kolonilere sahip GPAK'ların gözden kaçması da diğer bir sınırlayıcı etkendir ${ }^{2,3}$.

Sınırlı sayıda çalışma yapıımış olsa da, dünya genelinde sıklıkla izole edilen GPAK'ların bazı antibiyotiklere önemli oranda direnç geliştirdikleri saptanmıştır. Direnç oranları, coğrafi bölgelere, merkezlere, hatta aynı merkezde bulunan farklı servislere göre ve enfeksiyon türlerine göre farklııılar göstermektedir. GPAK'ların türler arasında da antimikrobiyal direnç oranları bakımından farkılıklar sergiledikleri tespit edilmiştir ${ }^{4,5}$.

Yapılan çalışmalarda, GPAK enfeksiyonlarına neden olan izolatlar çoğunlukla tür ayrımına gitmeksizin ele alınmış ya da çok az sayıda tür tayini yapılmıştır ${ }^{4,5}$. Diğer yandan, GPAK'larda son zamanlarda halen devam etmekte olan büyük taksonomik değişiklikler yapılmıştır ${ }^{6-9}$. Taksonomiye yeni katılan izolatların antibiyotiklere direnç profili ise henüz bilinmemektedir. GPAK izolatlarının tür düzeyinde antimikrobiyal duyarlılık paternlerinin saptanması gerekli olup bu durum etkili bir ampirik tedavi açısından çok önemlidir.

Bu çalışmada, hastanemiz mikrobiyoloji laboratuvarında çeşitli klinik örneklerden elde edilen enfeksiyon etkeni GPAK izolatlarının tür düzeyinde tanımlanması ve antibiyotik duyarlıık durumlarının belirlenmesi amaçlanmıştır.

\section{GEREÇ ve YÖNTEM}

Bu çalışma, Marmara Üniversitesi Sağlık Bilimleri Enstitüsü Etik Kurulu onayı ile gerçekleştirildi (Tarih: 26.01.2015 ve Karar No: 23). 


\section{İzolatların Tanımlanması}

Çalışmaya 2013-2015 yılları arasında Marmara Üniversitesi Hastanesi hastalarına ait klinik örneklerden elde edilen GPAK izolatları alındı. Apse $(n=35)$, doku biyopsisi $(n=30)$, batın içi apse örneği $(n=17)$, periton sıvısı $(n=7)$, plevra sıvısı $(n=6)$, kan $(n=4)$ ve eklem SIVISI $(n=1)$ örneklerinden üretilen ve tekrar etmeyen 100 patojen GPAK çalışmaya dahil edildi. Antibiyotik duyarlılık testi öncesi $-80^{\circ} \mathrm{C}^{\prime}$ de saklanan izolatlar, koyun kanı, K vitamini ve hemin ile zenginleştirilmiş Brucella agara ekildi. Mikroskobik olarak gram-pozitif kok görünümünde olan, aerotolerans testine göre zorunlu anaerop özellik gösteren izolatlar tanımlamaya alındı.

\section{"Matrix-assisted laser desorption ionization-time of flight mass spectrometry system (MALDI-TOF MS)" ile Tanımlama}

İzolatların tür düzeyinde tanımlanmaları VITEK ${ }^{\circledR}$ MS (bioMerieux, Fransa) analiz yöntemiyle gerçekleştirildi. Bakteri kültüründen birer koloni MALDI-TOF MS (VITEK MS; v3.0, bioMerieux, Fransa) slaytı üzerine yayılarak, üzerlerine $1 \mu$ l matriks çözeltisi (2,5-dihidroksibenzoik asit ve $\alpha$-siyano-4-hidroksisinnamik asit) damlatıldı ve kurumaya bırakılarak cihaza yerleştirildi. Elde edilen kütle spektrumları sistemin V3.0 bilgi veri tabanındaki spektrumlarla karşılaştırılarak bakteriler tanımlandı. Sistemin kalibrasyonu ve bakterilerin tanımlanma kontrolü için ATCC Escherichia coli 8739 suşu kullanıldı.

\section{S rRNA Geni Dizilemesi ile Tanımlama}

İzolatların tür tanımlanması 16S rRNA gen dizi analizi ile doğrulandı. Bakteri DNA'sı kaynatma yöntemiyle elde edildikten sonra, 16S rRNA genini kodlayan bölge evrensel 8UA (5'-AGA GTT TGA TCC TGG CTC AG-3') ve 907B (5'-CCG TCA ATT CMT TTA GTT T-3') primerleri kullanılarak polimeraz zincir reaksiyonu (PCR) ile amplifiye edildi ${ }^{10}$. Elde edilen PCR ürünleri dizi analizi ile incelendi (Triogene). Dizi analizi sonuçları NCBI-Blast veri tabanı kullanılarak incelendi (https://blast.ncbi.nlm.nih.gov/Blast.cgi).

\section{Antimikrobiyal Duyarlılık Testi}

Zenginleştirilmiş Brucella agarda üç kez peş peşe pasajlanarak canlandırılan GPAK izolatlarına antibiyotik duyarlıık testi uygulandı. İzolatların antibiyotik duyarlııkları "Clinical and Laboratory Standards Institute (CLSI: M11-A7)" önerileri doğrultusunda agar dilüsyon yöntemi kullanılarak belirlendi" ${ }^{11}$. Antimikrobiyal ilaçlar CLSI ve "European Committee on Antimicrobial Susceptibility Testing (EUCAST)" önerileri dikkate alınarak belirlendi ${ }^{11,12}$. K vitamini, hemin ve koyun kanı ile zenginleştirilmiş Brucella agar kullanılarak; penisilin G, amoksisilin/klavulanik asit, sefoksitin, meropenem, tetrasiklin, tigesiklin, eritromisin, klindamisin, metronidazol, kloramfenikol ve moksifloksasin antibiyotiklerinin her biri için seri dilüsyonlarda agar dilüsyon plakları hazırlandı. Bakterilerin Brucella sıvı besiyerinde bir gecelik inkübasyonu sonrası elde edilen taze kültürlerinden, son konsantrasyon $10^{5} \mathrm{cfu}$ olacak şekilde, agar dilüsyon plaklarına ekim yapıldı. Anaerop ortamda, $37^{\circ} \mathrm{C}^{\prime}$ de 48 saat inkübasyonun ardından üremenin olmadığı en düşük konsantrasyon minimum inhibitör konsantrasyonu (MiK) olarak kabul edildi. 
Tüm izolatların antibiyotik duyarlılık sonuçları, hem CLSI hem de EUCAST dokümanlarına göre değerlendirildi. Öncelikle EUCAST dokümanında yer alan sınır değerler dikkate alındı. Bu rehberde belirtilmeyen antibiyotik duyarlııı sınır değerleri için CLSı önerileri dikkate alındı. Her iki dokümanda da anaerobik bakterilerde sınır değeri verilmeyen eritromisin için MiK aralıkları ve $\mathrm{MiK}_{50}$ ve $\mathrm{MiK}_{90}$ değerleri olarak hesaplandı. Tigesiklin için ise "Food and Drug Administration (FDA)" tarafından önerilen sınır değerler (duyarlı: $\leq$ $2 \mathrm{mg} / \mathrm{L}$, dirençli: $\geq 8 \mathrm{mg} / \mathrm{L}$ ) dikkate alındı ${ }^{13}$.

Beta-laktamaz aktivitesinin varlığını araştırmak için kromojenik sefalosporin testi (BBL DrySlide Nitrocefin, BD, ABD) kullanıldı ${ }^{4}$.

\section{BULGULAR}

VITEK MS (bioMérieux, Fransa) ile yapılan tanımlamada izolatların \%41'i Parvomonas micra, \%34'ü Finegoldia magna, \%14'ü Peptoniphilus asaccharolyticus ve \%10'u Peptostreptococcus anaerobius olarak \%99.9 kesinlikte tanımlanmıştır. Bir izolat ise tanımlanamamıştır.

16S rRNA gen dizi analizine göre izolatların 41'i \%99 benzerlikle P.micra, 34'ü \%99 benzerlikle F.magna olarak tanımlanmıştır. Bu sonuçlar MALDI-TOF MS sonuçlarıyla aynı bulunmuştur. Diğer izolatlardan 14'ü P.asaccharolyticus ve Peptoniphilus harei türlerine \%99 benzerlik göstermiştir; bu izolatlar MALDI-TOF MS ile \%99.9 olasılıkla P.asaccharolyticus şeklinde identifiye edilmiştir. Toplam 10 izolat ise P.anaerobius ve ayn zamanda Peptostreptococcus stomatis'e \%99 benzer bulunmuştur. MALDI-TOF MS ile bu izolatlar P.anaerobius olarak değerlendirilmiştir.

MALDI-TOF MS ile tanımlanamayan bir izolat 16S rRNA gen dizilemesi ile \%91 oranıyla Anaerococcus octavius (NR_026360.1) izolatı ile benzer bulunmuştur. Tanımlanan izolatların izole edildikleri klinik örneklere göre dağılımı Tablo I'de verilmiştir.

Çalışmaya alınan izolatların \%42'si tüm antibiyotiklere duyarlı bulunmuştur. GPAK türlerinin 11 antimikrobiyal ilaca karşı duyarlılık profilleri, antibiyotiklerin MiK sınır değerleri, MiK $_{50}$ ve MiK ${ }_{90}$ verileri Tablo II'de gösterilmiştir. İzolatların tamamı sefoksitine (orta dirençli bir izolat hariç), meropeneme, tigesikline ve metronidazole duyarlı bulunmuştur. Penisiline \%5, amoksisilin/klavulonik aside \%4, diğer antibiyotiklerden kloramfenikol, klindamisin, moksifloksasin ve tetrasikline ise sırasıyla; \%3, \%14, \%24 ve \%31 oranlarında direnç saptanmıştır.

Direncin türlere göre dağılımı irdelendiğinde, türler arasında farklılıklar gözlenmiştir. P.micra izolatlarının çoğu antibiyotiklere duyarlı bulunmuştur. Buna karşın, Peptoniphilus türlerinde en yüksek direnç oranları tetrasikline (\%93) ve klindamisine (\%29) karşı gözlenmiştir. Genel anlamda peptostreptokok türlerinde antibiyotiklere yüksek direnç oranı tespit edilmiştir (Tablo III). İzolatların \%11'i üç veya daha fazla grup antibiyotiğe direnç göstermiştir (Tablo IV). Çok antibiyotiğe dirençli izolatlar sırasıyla F.magna $(n=5)$, Peptostreptococus $(n=$ 4) ve Peptoniphilus ( $n=2$ ) türlerinden oluşmuştur. Penisiline dirençli izolatlar beta-laktamaz aktivitesi göstermemiş olmakla birlikte diğer antibiyotiklere de direnç göstermiştir. 


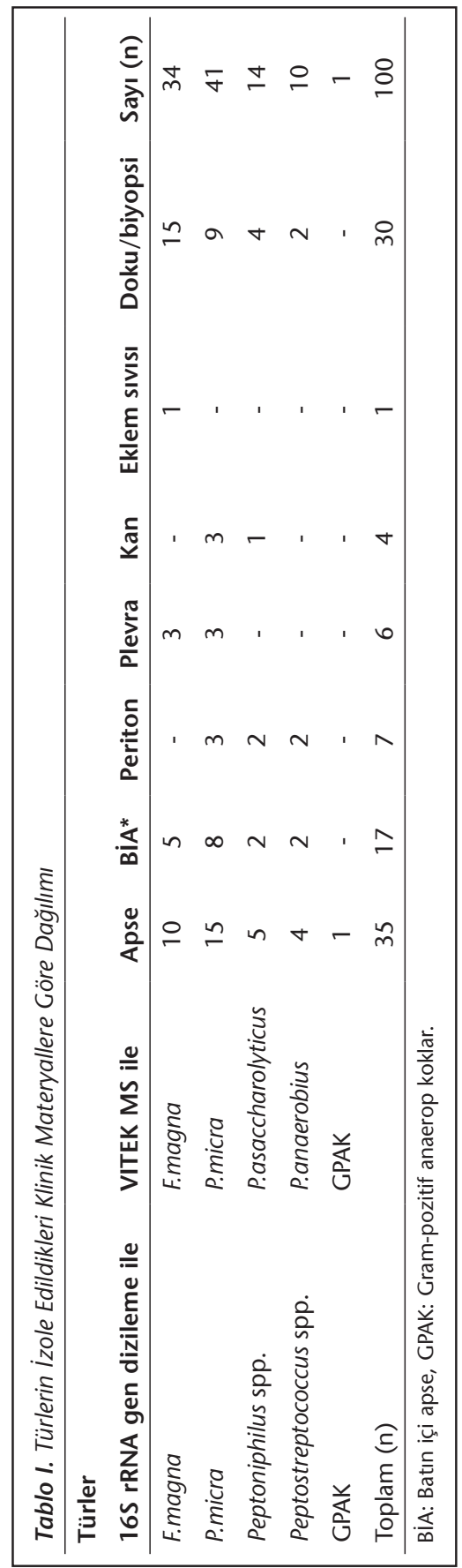




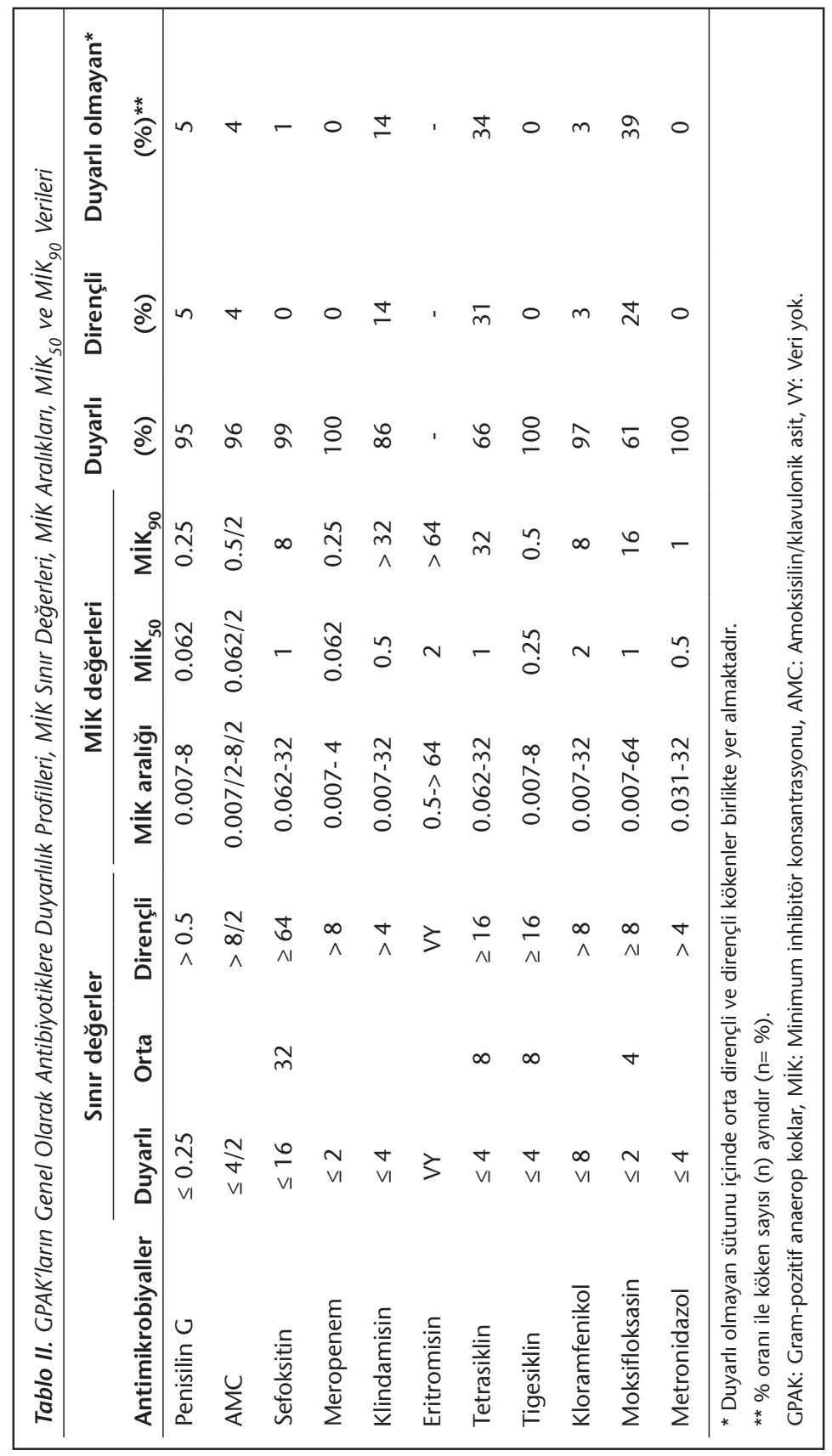




\begin{tabular}{|c|c|c|c|c|c|}
\hline \multirow[b]{2}{*}{ GPAK ve antimikrobiyaller } & \multicolumn{3}{|c|}{ Mik değerleri } & \multicolumn{2}{|c|}{ Oran \% } \\
\hline & MiK aralıkları & $\mathrm{Mik}_{50}$ & Mik $_{90}$ & Duyarlı & $\begin{array}{c}\text { Duyarlı } \\
\text { olmayan }\end{array}$ \\
\hline \multicolumn{6}{|l|}{ Parvimonas micra $(n=41)$} \\
\hline Penisilin & $<0.007-0.125$ & $<0.007$ & 0.031 & 100 & 0 \\
\hline AMC & $<0.007 / 2-1 / 2$ & 0.007 & 0.125 & 100 & 0 \\
\hline Klindamisin & $<0.007-8$ & 0.125 & 0.5 & 95.1 & 4.9 \\
\hline Tetrasiklin & $0.062-32$ & 0.125 & 1 & 97.6 & 2.4 \\
\hline Kloramfenikol & $0.007-8$ & 1 & 2 & 100 & 0 \\
\hline Moksifloksasin & $0.015-8$ & 1 & 4 & 83 & 17 \\
\hline \multicolumn{6}{|l|}{ Finegoldia magna $(\mathrm{n}=34)$} \\
\hline Penisilin & $0.015-0.5$ & 0.15 & 0.25 & 100 & 0 \\
\hline AMC & $0.062 / 2-0.5 / 2$ & 0.125 & 0.5 & 100 & 0 \\
\hline Klindamisin & $<0.007->32$ & 2 & $>32$ & 79.4 & 20.6 \\
\hline Tetrasiklin & $0.062-32$ & 2 & 32 & 61.8 & 38.2 \\
\hline Kloramfenikol & $1-32$ & 4 & 8 & 94.1 & 5.9 \\
\hline Moksifloksasin & $0.25->32$ & 4 & 32 & 38.2 & 61.8 \\
\hline \multicolumn{6}{|l|}{ Peptoniphilus spp. $(n=14)$} \\
\hline Penisilin & $0.031-2$ & 0.15 & 0.25 & 92.8 & 7.1 \\
\hline AMC & $<0.007 / 2-2 / 2$ & 0.007 & 0.062 & 100 & 0 \\
\hline Klindamisin & $0.31->32$ & 1 & $>32$ & 71.4 & 28.6 \\
\hline Tetrasiklin & $0.062-64$ & 32 & 64 & 21.4 & 92.9 \\
\hline Kloramfenikol & $0.031-8$ & 2 & 2 & 100 & 0 \\
\hline Moksifloksasin & $0.05-64$ & 1 & 64 & 71.4 & 28.6 \\
\hline \multicolumn{6}{|c|}{ Peptostreptococcus spp. $(n=10)$} \\
\hline Penisilin & $<0.007-8$ & 0.25 & 4 & 60 & 40 \\
\hline AMC & $0.125 / 2-8 / 2$ & 0.5 & $>8$ & 60 & 40 \\
\hline Klindamisin & $0.062-8$ & 0.125 & 2 & 90 & 10 \\
\hline Tetrasiklin & $0.062-32$ & 16 & 32 & 10 & 90 \\
\hline Kloramfenikol & $1->32$ & 1 & 2 & 90 & 10 \\
\hline Moksifloksasin & $0.25-16$ & 16 & 16 & 30 & 70 \\
\hline
\end{tabular}




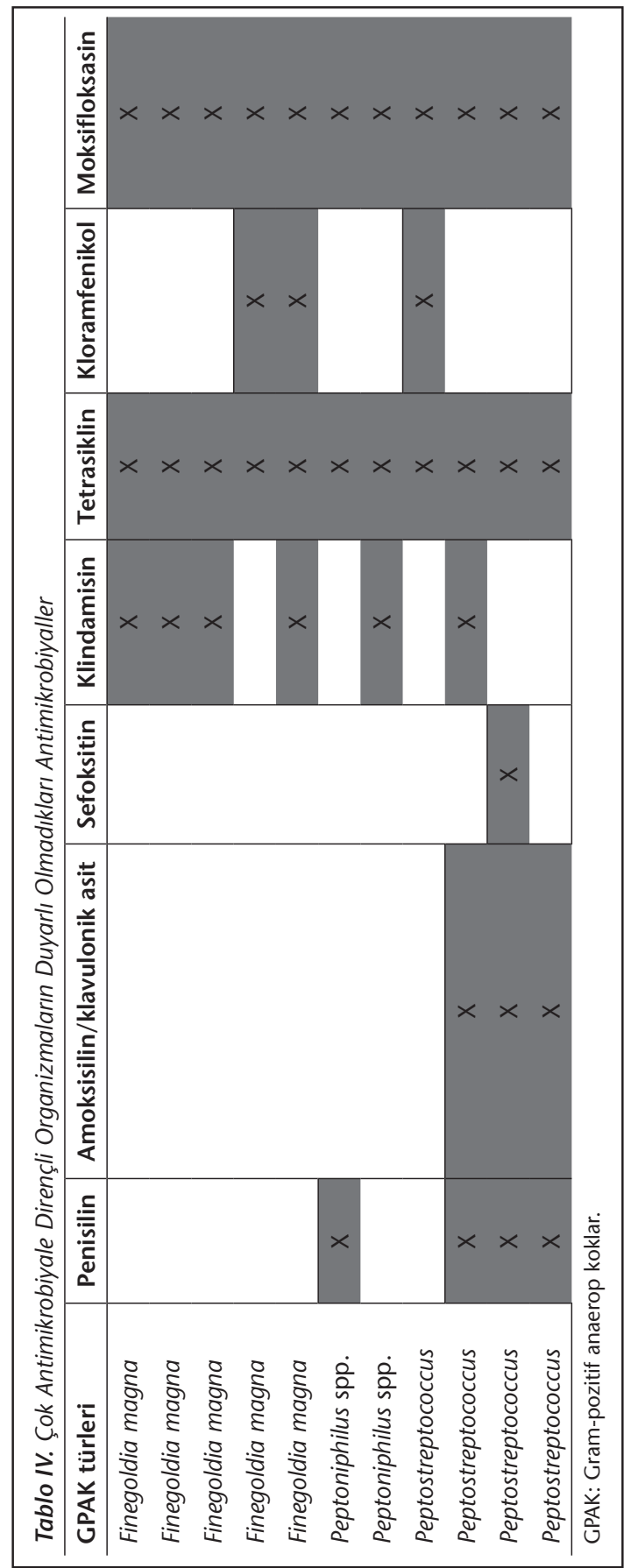




\section{TARTIŞMA}

Bu çalışmada, 2013-2015 yılları arasında Marmara Üniversitesi Hastanesi Laboratuvarında klinik örneklerden elde edilen GPAK izolatlarının antibiyotiklere duyarlılık durumları araştırılmıştır. Elde edilen veriler üç unsuru öne çıkartmıştır: (i) İzolatlarımız dört ana GPAK cinsini içermekte olup cinsler arasında antibiyotiklere duyarlılık profili çeşitlilik göstermektedir; en fazla orana sahip Parvomonas izolatları diğer türlere göre daha duyarlı bulunmuştur. (ii) Klindamisin, tetrasiklin ve moksifloksasine yüksek oranda direnç saptanmıştır. (iii) İzolatların \%11'i üç veya daha fazla grup antimikrobiyal ilaca direnç göstermiştir.

Bu çalışma sonuçları, bu konuda yayımlanmış diğer direnç verileriyle karşılaştırıldığında değerlendirmede birtakım zorluklar fark edilmiştir. Türkiye'den, GPAK'ların antibiyotiklere duyarlııklarını referans yöntemlerle araştıran herhangi bir çalışmaya rastlanmamıştır. Ancak 2010 yılında Doğan ve arkadaşları tarafından yapılan klinik örneklerden izole edilen anaerop bakterilerin ele alındığı, gradiyent test (AB Biodisk, İsveç) yöntemiyle penisilin G, klindamisin, sefoksitin, metronidazol, piperasilin/tazobaktam ve imipeneme karşı duyarlııılarının araştırıldığı çalışmada ${ }^{14}$, GPAK izolatlarının $(n=7)$ çalışılan antibiyotiklere duyarlı olduğu bulunmuştur. Dünya verileri incelendiğinde ise, çalışmalarda farklı duyarlılık yöntemlerinin kullanıldığı, farklı antibiyotiklerin test edildiği veya sonuçları değerlendirmek için farklı rehberlerin (CLSI/EUCAST) sınır değerlerinin alındığı, bazı çalışmalarda ise sadece MiK $_{50}$ ve MiK ${ }_{90}$ değerlerinin verildiği görülmüştür ${ }^{15-19}$. Çalışmamızda anaerop bakterilerin duyarlılıklarını saptamak için CLSI tarafından önerilen standart yöntem olan agar dilüsyon testi uygulanmış ve anaeroplar üzerine etkili olduğu bilinen antimikrobiyal ilaçlar çalışılmıştır ${ }^{11}$.

Klinik örneklerden GPAK türlerinin izole edilme oranlarında merkezlere göre farklılıklar gözlenmektedir. On Avrupa ülkesini kapsayan, daha çok yumuşak doku enfeksiyonu etkenlerinden oluşan 299 GPAK'ın ele alındığı ve 2008 yılında yayımlanmış çok merkezli bir çalışmada ${ }^{20}$ izolatların çoğunluğunu F.magna (\%37.1) oluşturmuş, bunu sırasıyla P.micra (\%17.7), P.harei (\%14.7), A.vaginalis (\%7.0) ve P.anaerobius (\%6.7) izlemiştir. Kanser hastalarından izole edilen GPAK'ların test edildiği bir başka çalışmada ${ }^{21}$, F.magna (\%47) birinci sırada yer almış, bunu P.harei (\%28), P.micra ve P.anaerobius izlemiştir. Çalışmamızda P.micra en fazla sayıda izole edilmiş, F.magna ise ikinci sırada yer almıştır. Test edilen klinik örneğin cinsine göre izole edilen GPAK türlerinde farklılıklar gözlenebilmektedir. Çalışmalar irdelendiğinde P.micra daha çok batın içi enfeksiyonlarında ve steril vücut sıvılarından izole edilmiştir. Çalışmamızda P.micra izolatlarının önemli kısmı $(n=17)$ batın içi apselerinden olmak üzere kan, plevra ve periton sıvıları gibi klinik örneklerden üretilmiştir ${ }^{1}$. Peptoniphilus izolatları için VITEK MS \%99.9 doğrulukla P.asaccharolyticus olarak tanımlarken, 16S rRNA gen dizilemesi aynı izolat için iki Peptoniphilus türüne \%99 benzerlikle P.asaccharolyticus ve P.harei sonucunu vermiştir. Wildeboer-Veloo ve arkadaşları yaptıkları çalışmada ${ }^{22}$, enfeksiyon etkeni olan GPAK türlerinin 16S rRNA gen dizi analizi ile tanımlamada aynı sorunlarla karşılaşmışlardır. Araştırmacılar bunu, fenotipik özellikleri bakımından benzerlik gösteren iki Peptoniphilus izolatından P.harei'nin yanlışlık- 
la P.asaccharolyticus olarak tanımlanabileceği şeklinde yorumlamışlardır. Hatta gen bankasına yanlışlıkla P.harei'ye ait bilgilerin P.asaccharolyticus'a ait bilgiler şeklinde girilmiş olabileceğini ileri sürmüşlerdir ${ }^{23}$.

Antibiyotiklere duyarlılık sonuçları temel alınarak sonuçlarımız değerlendirildiğinde, dünya verileriyle benzerlikler ve farklılıklar sergiledikleri görülmektedir. Dördü P.anaerobius, biri Peptoniphilus türü olmak üzere izolatlarımızın 5 (\%5)'i penisiline dirençli bulunmuştur. P.anaerobius izolatlarının aynı zamanda amoksisilin/klavulonik aside direnç, sefoksitine ise yüksek Mik değeri (birisi orta dirençli) geliştirdiği gözlenmiştir. Penisiline dirençli izolatların hiçbirinde beta-laktamaz aktivitesi saptanmamıştır. Bazı ülkelerde GPAK izolatlarında \%4 ile \%15'lere varan oranda penisiline direnç bildirilmiştir. Betalaktam/beta-laktamaz inhibitörlerine ise yaklaşık \%3 oranında direnç bildirilmiştir ${ }^{15-18,20}$. Saptanan direncin beta-laktamaz üretimine bağlı olmayıp, penisilin bağlayan hedef bölgelerdeki değişimlerden kaynaklandığı ileri sürülmüştür. İzolatlarımızdaki direnç profili göz önüne alındığında aynı direnç mekanizmasının rol oynadığını söyleyebiliriz. Diğer çalışmalarda olduğu gibi izolatlarımızın tamamı meropeneme duyarlı bulunmuştur.

Penisiline allerjisi olan kişilerde geniş antianaerop etkiye sahip klindamisin kullanılmaktadır. Klindamisin özellikle diş ve dişeti enfeksiyonları ve aspirasyon pnömonisi tedavisinde başarılı sonuçlar vermektedir. Farklı ülkelerde yapılan çalışmalarda, GPAK izolatlarında \%7-20 oranında klindamisine direnç bildirilmiştir ${ }^{15-18,20,21}$. Ancak \%55 ile en yüksek direnç oranı Tayvan'dan açıklanmıştı ${ }^{25}$. İzolatlarımızın tamamı değerlendirildiğinde direnç oranımız \%14 saptanmış, bununla beraber türler arasında farklılıklar görülmüştür. Direnç oranı Peptoniphilus izolatlarında daha yüksek bulunmuştur.

Hastanemizde genel anlamda GPAK'ların tetrasikline direnç oranı \%31, tür düzeyinde irdelendiğinde ise Peptostreptococcus ve Peptoniphilus izolatlarının \%90'ından fazlasında direnç saptanmıştır. Tetrasiklin ile ilgili yapılan çalışmalar sınırlı olmakla birlikte İngiltere'de GPAK izolatlarının \%41.6'sında, tür bazında ise Peptostreptococcus ve P.micra izolatlarının \%60'ında direnç bildirilmiştir ${ }^{16}$. Tetrasiklinin anaeroplar üzerine etkisi zayıf olmakla birlikte, tetrasiklinin bir analoğu olan tigesiklin gerek GPAK izolatları gerekse diğer anaeroplar üzerine yüksek etkiye sahiptir. Avrupa çapında yapılan bir çalışmada GPAK izolatlarının tamamının tigesikline duyarlı, MiK $_{90}$ değerinin ise $0.12 \mathrm{mg} / \mathrm{L}$ olduğu saptanmıştır $^{27}$. Benzer şekilde izolatlarımızın tamamı tigesikline duyarlı bulunmuştur.

Farklı ülkelerde yapılan çalışmalarda GPAK izolatları arasında florokinolonlara giderek artan ve \%14-27 arasında değişen direnç oranları bildirilmiştir ${ }^{5}$. Belçika'da yapılan bir çalışmada, 37 GPAK izolatı arasında moksifloksasin direnci \%22 olarak saptanmıştır ${ }^{18}$. Başka bir çalışmada ise levofloksasine direnç, P.micra izolatlarında \%8.9, F.magna izolatlarında \%27.6 oranında bulunmuştur ${ }^{26}$. Çalışmamızda moksifloksasine direnç GPAK izolatlarının \%39'unda saptanmıştır. En yüksek direnç Peptostreptococcus izolatlarında (\%60) bulunurken, F.magna izolatlarında \%41.1 oranında direnç izlenmiştir. Direnç oranının yüksek olması florokinolonların çeşitli enfeksiyonların tedavisinde yaygın kullanılıyor olmasına bağlanabilir. 
Toksik yan etkileri nedeniyle pek kullanılmayan kloramfenikole karşı dirençli izolatlarımızın bulunması dikkat çekicidir. Diğer ülkelere ait veriler incelendiğinde yalnız Belçika'dan yıllar içinde \%1-3 oranında değişen direnç bildirilmiştir ${ }^{28}$.

Anaeroplara bağlı enfeksiyonların tedavisinde sık kullanılan metronidazole karşı tüm izolatlarımızın duyarlı olması yüz güldürücüdür. Dünya verileri incelendiğinde, GPAK izolatlarının en az \%90-95'inin metronidazole duyarlı olduğu görülmektedir ${ }^{5}$. Dünyada nim geni taşıyan metronidazole dirençli F.magna ve P.micra izolatları tanımlanmış29 ve en yüksek direnç oranı \%28.6 ile Hırvatistan'dan bildirilmiştir ${ }^{30}$.

Çoklu antibiyotik dirençli izolatlarımızın oranı kaygı verici boyutlardadır. Bu konuda yapılmış, özellikle çok ilaca dirençli GPAK'ların ele alındığı herhangi bir çalışmaya rastlanmamıştır. Ancak, F.magna izolatlarının diğerlerine göre daha dirençli olduğuna dair bilgi bulunmaktadır ${ }^{21}$. Çalışmamızda F.magna ve Peptostreptococus türlerinin her ikisi çok ilaca dirençli izolatlar arasında önemli paya sahiptir.

Sonuç olarak, elde ettiğimiz veriler GPAK enfeksiyonlarının ampirik tedavisinde uygun antibiyotiği seçmemiz için yol gösterici olacaktır. Çalışmamızda meropenem, tigesiklin ve metronidazol ampirik tedavide güvenle kullanabileceğimiz en etkili antimikrobiyal ilaçlar olmuştur; ancak meropenemin direnç potansiyeline sahip diğer organizmaların eşlik ettiği ağır mikst enfeksiyonların tedavisine ayrılması daha doğru olacaktır. GPAK'lara bağlı enfeksiyonların tedavisinde sıklıkla kullanılan penisilin ve amoksisilin/klavulonik aside dirençli izolatlarımız bulunmaktadır, Bu mikroorganizmalar diğer antibiyotiklere de direnç göstermektedir. İzolatlarımızda klindamisin, tetrasiklin ve moksifloksasine yüksek düzeylerde direnç bulunması, ampirik tedavide bu ilaçların seçilmesine engel teşkil etmektedir. Başarılı bir tedavinin yapılabilmesi için etken mikroorganizmanın tür düzeyinde tanımlanması ve duyarlılık durumlarının belirlenmesi gerekmektedir.

Türkiye'de bugüne kadar yapılmış en yüksek sayıda GPAK izolatına sahip antibiyotik duyarlııı sonuçlarını sunması nedeniyle çalışmamızın, hastanemiz ve ülkemiz için iyi bir sürveyans verisi olacağı düşüncesindeyiz.

\section{ETIK KURUL ONAYI}

Bu çalışma, Marmara Üniversitesi Sağlık Bilimleri Enstitüsü Etik Kurulu onayı ile gerçekleştirildi (Tarih: 26.01.2015 ve Karar No: 23).

\section{ÇIKAR ÇATIŞMASI}

Yazarlar bu makale ile ilgili herhangi bir çıkar çatışması bildirmemişlerdir.

\section{KAYNAKLAR}

1. Murphy EC, Frick IM. Gram-positive anaerobic cocci-commensals and opportunistic pathogens. FEMS Microbiol Rev 2013; 37(4): 520-53.

2. Tunçkanat F. Anaerop bakterilerin genel özellikleri, pp: 2319-63. In: Topçu AW, Söyletir G, Doğanay M (eds). Enfeksiyon Hastalıkları ve Mikrobiyolojisi Cilt 2. 2008, 3. Baskı, Nobel Tıp Kitapevleri, İstanbul. 
3. Song Y, Liu C, Finegold SM. Development of a flow chart for identification of gram-positive anaerobic cocci in the clinical laboratory. J Clin Microbiol 2007; 45(2): 512-6.

4. Brook I, Wexler MH, Ellie JC, Goldstein EJC. Antianaerobic antimicrobials: spectrum and susceptibility testing. Clin Microbiol Rev 2013; 26(3): 526-46.

5. Schuetz AN. Antimicrobial resistance and susceptibility testing of anaerobic bacteria. Clin Infect Dis 2014; 59(5): 698-705.

6. Murdoch DA. Gram-positive anaerobic cocci. Clin Microbiol Rev 1998; 11(1): 81-120.

7. Ezaki T, Kawamura Y, Li N, Li ZY, Zhao L, Shu S. Proposal of the genera Anaerococcus gen. nov., Peptoniphilus gen. nov. and Gallicola gen. nov. For members of the genus Peptostreptococcus. Int J Syst Evol Microbiol 2001; 51(Pt 4): 1521-8.

8. Ezaki T, Kawamura Y, Li N, Li ZY, Zhao L, Shu S. Transfer of Peptococcus indolicus, Peptococcus asaccharolyticus, Peptococcus prevotii and Peptococcus magnus to the genus Peptostreptococcus and proposal of Peptostreptococcus tetradius sp. nov. Int J Syst Bacteriol 1983; 33: 683-98.

9. Ulger-Toprak N, Liu C, Summanen PH, Finegold SM. Murdochiella asaccharolytica gen. nov., sp. nov., a gram-stain-positive, anaerobic coccus isolated from human wound specimens. Int J Syst Evol Microbiol 2010; 60(Pt 5): 1013-6.

10. Song Y, Liu C, McTeague M, Finegold SM. 16S ribosomal DNA sequence-based analysis of clinically significant gram positive anaerobic cocci. J Clin Microbiol 2003; 41(4): 1363-9.

11. Clinical and Laboratory Standards Institute. Methods for Antimicrobial Susceptibility Testing of Anaerobic Bacteri, Approved Standards-7 ${ }^{\text {th }}$ Edition, M11-A7, CLSI, Pennsylvania, USA, 2007.

12. European Committee on Antimicrobial Susceptibility Testing, 2015. Setting breakpoints for existing antimicrobial agents. EUCAST SOP 2.0.European Committee on Antimicrobial Susceptibility Testing, Växjö,Sweden.

13. FDA (2005). FDA approved drug products: Tygacil. https://www.accessdata.fda.gov/drugsatfda_docs/ label/2005/021821lbl.pdf

14. Doğan M, Baysal B. Identification of anaerobic bacteria isolated from various clinical specimens and determination of antibiotic susceptibilities. Mikrobiyol Bul 2010; 44(2): 211-9.

15. Boyanova L, Osmanliev D, Petrov D, Mitov I, Usunova I, Petrov S, et al. Anaerobic cocci and their resistance patterns to penicillin, cefoxitin, clindamycin and metronidazole: a Bulgarian study. Clin Microbiol Infect 2000; 6(11): 623-4.

16. Brazier JD, Hall V, Morris TE, Gal M, Duerden BI. Antibiotic suspectibilities of gram-positive anaerobic cocci: results of a sentinel study in England and Wales. J Antimicrob Chemother 2003; 52(2): 224-8.

17. Goldstein EJ, Citron DM, Merriam CV, Warren YA, Tyrrell KL, Fernandez HT. Comparative in vitro susceptibilities of 396 unusual anaerobic strains to tigecycline and eight other antimicrobial agents. Antimicrob Agents Chemother 2006; 50(10): 3507-13.

18. Wybo I, Pierard D, Verschraegen I, Reynders M, Vandoorslaer K, Claeys G, et al. Third Belgian multicentre survey of antibiotic susceptibility of anaerobic bacteria. J Antimicrob Chemother 2007; 59(1): 132-9.

19. Veloo AC, Welling GW, Degener JE. Antimicrobial susceptibility of clinically relevant gram-positive anaerobic cocci collected over a three-year period in the Netherlands. Antimicrob Agents Chemother 2011; 55(3): 1199-203.

20. Brazier J, Chmelar D, Dubreuil L, et al; ESCMID Study Group on Antimicrobial Resistance in Anaerobic Bacteria. European surveillance study on antimicrobial susceptibility of Gram-positive anaerobic cocci. Int J Antimicrob Agents 2008; 31(4): 316-20.

21. Shilnikova II, Dmitrieva NV. Evaluation of antibiotic susceptibility of gram-positive anaerobic cocci Isolated from cancer patients of the N. N. Blokhin Russian Cancer Research Center. J Pathog 2015; 2015: 648134.

22. Wildeboer-Veloo AC, Harmsen HJ, Welling GW, Degener JE. Development of 16 S rRNA-based probes for the identification of Gram-positive anaerobic cocci isolated from human clinical specimens. Clin Microbiol Infect 2007; 13 (10): 985-92. 
23. Veloo AC, Welling GW, Degener JE. Mistaken identity of Peptoniphilus asaccharolyticus. J Clin Microbiol 2011; 49(3): 1189.

24. Nagy E. Anaerobic infections update on treatment considerations. Drugs 2010; 70(7): 841-58.

25. Teng LJ, Hsueh PR, Tsai JC, Liaw SJ, Ho SW, Luh KT. High incidence of cefoxitin and clindamycin resistance among anaerobes in Taiwan. Antimicrob Agents Chemother 2002; 46(9): 2908-13.

26. Koeth LM, Good CE, Appelbaum PC, Goldstein EJ, Rodloff AC, Claros M, et al. Surveillance of susceptibility patterns in 1297 European and US anaerobic and capnophilic isolates to co-amoxiclav and five other antimicrobial agents. J Antimicrob Chemother 2004; 53(6): 1039-44.

27. Nagy E. In vitro activity of tigecycline and comparators against European compilation of anaerobes collected as part of the Tigecycline Evaluation and Surveillance Trial (TEST). Scand J Infect Dis 2010; 42(1): 33-8.

28. Wybo I, Van den Bossche D, Soetens O, Vekens E, Vandoorslaer K, Claeys G, et al. Fourth Belgian multicentre survey of antibiotic susceptibility of anaerobic bacteria. J Antimicrob Chemother 2014; 69(1): 155-61.

29. Alauzet C, Lozniewski A, Marchandin H. Metronidazole resistance and nim genes in anaerobes: a review. Anaerobe 2019; 55: 40-53.

30. Novak A, Rubic Z, Dogas V, Goic-Barisic I, Radic M, Tonkic M. Antimicrobial susceptibility of clinically isolated anaerobic bacteria in a university hospital centre Split, Croatia in 2013. Anaerobe 2015; 31: 31-6. 